\title{
REKAYASA MESIN PEMBUAT PAKAN IKAN LELE PELLET)
}

\author{
Achmad Nurhidayat ${ }^{1)}$, Silvia Yulita Ratih Setyo Raha ${ }^{2)}$ \\ ${ }^{1)}$ Program Studi Teknik Mesin, ${ }^{2)}$ Program Studi Teknik Sipil \\ Fakultas Teknik, Universitas Surakarta (UNSA) Jl. Raya Palur Km. 5, Surakarta \\ *Email: achkun72@yahoo.com; achkunujang@gmail.com
}

\begin{abstract}
ABSTRAK
Perubahan harga bahan pokok konsumsi sehari-hari yang cenderung meningkat dipasaran berdampak terhadap kelompok peternak lele dimana harga pakan buatan (pelet) pabrikan/toko juga semakin mahal. Disisi lain harga jual lele yang cukup murah sehingga keuntungan yang didapat dari usaha para peternak tersebut sangat minim. Biaya pembelian pakan merupakan salah satu penyebab rendahnya pendapatan, padahal merupakan aspek polivalen sebagian dari mereka sebagai mata pencaharian. Karena itu dipandang perlu adanya pendampingan program intensifikasi produksi lele melalui mekanisasi pakan mandiri/buatan sendiri, agar produksi yang dihasilkan mempunyai nilai lebih secara kualitas serta ekonomis yang memadai dan swasembada. Tujuan pengabdian masyarakat ini adalah merancang dan menciptakan IPTEK bagi Masyarakat yang dibutuhkan oleh pengusaha kecil dalam hal ini pengusaha lele, untuk meminimalkan ketergantungan pakan buatan toko, tetap menjaga kualitas dan kuantitas produksi lele, meningkatkan kerjasama antar pemberdaya masyarakat khususnya pengusaha lele kecil dan menengah dan pemberdayaan peran perguruan Tinggi dalam membantu kegiatan ekonomi masyarakat. Bahan pembuatan pelet (pakan lele) berbahan dasar limbah yaitu tepung roti kadaluwarsa, ikan asin kadaluwarsa (busuk/duri ikan sisa warung/tulang sisa), kotoran puyuh, sampah bulu ayam potong, minyak ikan (diambil dari rebusan ikan asin/duri ikan). Mesin pembuat pelet merupakan alat yang berfungsi untuk menghancurkan bahan, mencampur dan mencetak pelet dengan kapasitas produksi mencapai hingga $200 \mathrm{~kg} / \mathrm{jam}$. Mesin cetak pelet sangat efektif untuk menghasilkan pakan ternak dengan bentuk hasil pakan yang mudah dimakan lele. Strategi dalam penyampaian materi dilakukan dengan pelatihan serta praktek langsung pembuatan pakan dan budidaya lele yang ekonomis. Hasil dari program pengabdian masyarakat ini peternak lele telah dibekali edukasi teknologi pembuatan pakan lele (pellet) dari macam bahan baku, komposisi, mesin/alat pembuat pellet, proses produksi hingga pengeringan serta penyimpanan pakan yang aman. Mitra juga dibekali tentang pemilihan bibit lele kualitas, pembesaran/perawatan pertumbuhan lele yang normal, kolam ideal, masa panen, strategi penjualan ikan lele secara mandiri atau kelompok. Mitra telah mandiri dan swasembada memproduksi pakan lele (pellet) bahkan sebagian produk dari jumlah hasil produk dibeli oleh ternak lele lain yang membutuhkan. Harga pellet dari mitra dapat ditekan menjadi Rp 5.500/kg-7.000/kg jauh lebih murah (tergantung jauh/dekat pengadaan bahan baku) sehingga dibawah harga pakan toko/pabrik yang mencapai Rp. $9.500 / \mathrm{kg}$ untuk kualitas nomer 1.
\end{abstract}

Kata kunci : lele, limbah/kotoran, pelet

\section{PENDAHULUAN}

Desa Ngringo, merupakan desa dengan penduduk terpadat di Kabupaten Karanganyar, dengan jumlah penduduk menurut data per-tahun 2013 dari 0 tahun sebanyak 28392 jiwa dan menempati wilayah seluas 25,55 $\mathrm{km}^{2}$. Desa Ngringo berbatasan pada sisi timur dengan Desa Dagen, Desa Jetis, Desa Sroyo, sisi selatan dengan
Kabupaten Sukoharjo, sisi barat Kota Surakarta dan sisi utara Kecamatan Gondangrejo, Kabupaten Karanganyar (topografi.jaten, 2013).

Sebagian besar wilayahnya terdiri atas dataran sedang dengan berbagai potensi yang sudah dikembangkan seperti pertanian persawahan dan perkebunan, peternakan, perikanan, pertokoan dan perdagangan. Dua 
tahun terakhir ini banyak yang mulai bisnis/usaha budidaya perikanan air tawar yang dikolaborasi dengan peternakan ayam/puyuh dan perkebunan. Alasan mereka tumbauhnya kesadaran masyarakat akan pentingnya usaha peningkatan gizi keluarga dan peningkatan nilai ekonomi yang telah dirasakan oleh berbagai pihak. Budidaya perikanan air tawar yang umum di Desa Ngringo antara lain jenis ikan mujahir, nila, gurami, patin dan lele. Sampai dengan tahun 2014 per-Agustus, tercatat ada sekitar 51 pembudidaya ikan air tawar di Desa Ngringo baik individu/keluarga atau kelompok. Namun yang paling diminati adalah jenis ikan lele, diantaranya kelompok usaha bersama (patungan) UKM peternak lele 'SURYONO' dan UKM peternak lele 'SARANA INDAH' tepatnya keduanya beralamatkan di Dusun Gunungsari, Ngringo, Jaten, Karanganyar dan sudah lebih 5 tahun berjalan menekuni usahanya.

Mitra UKM peternak lele 'SURYONO' dan UKM peternak lele 'SARANA INDAH' tersebut sangat berharap adanya perubahan yang semakin baik dalam usahanya, diantaranya: 1 . berharap untuk mengurangi ketergantungan bahkan tidak lagi menggunakan pakan buatan beli dari toko yang relatif mahal (swasembada pakan mandiri /buatan sendiri), 2. berharap mampu mengatasi permasalahan produksi lele secara kualitas dan kuantitas, sehingga mampu bersaing dipasaran, serta 3. mitra memahami pengetahuan dan pengalaman pengaruh faktor luar terhadap pertumbuhan lele, sehingga dapat mengantisipasi dini (preventif) setiap ada gejala yang tidak baik dimaksud.

Karena itu dipandang perlu adanya pendampingan program intensifikasi produksi lele melalui mekanisasi pakan mandiri/buatan sendiri, agar nilai ekonomi produksi lele yang dihasilkan semakin meningkat/baik.

\section{METODE PELAKSANAAN}

Tahapan langkah pelaksanaan program pengabdian masyarakat ini yaitu pembuatan mesin penghancur bahan baku, pencetak sekaligus pengering pelet dan pelaksanaan pelatihan pembuatan pakan mandiri menggunakan limbah yang ada di sekitar. Pelaksanaan program diawali dengan sosialisasi perhitungan kebutuhan jumlah pakan lele tiap peternak, kemudian diadakan penyuluhan di tempat pertemuan kelompok mitra. Setelah itu melakukan eksplorasi dan inventarisasi tentang bahan limbah yang bisa digunakan, dilanjutkan Tim pengabdian masyarakat memberikan pelaksanaan program hasil survey dilapangan kepada mitra terkait.

Adapun program-program tersebut adalah rekayasa mesin pembuat pelet. Mesin ini mempunyai 3 fungsi sekaligus yaitu untuk menghancurkan atau menggiling bahan baku pakan ikan/pelet sebagai alat pencetak pelet dan pengering pelet. yang merupakan satu. Mekanisme mesin dirancang untuk menghancurkan bahan pakan (row material) terdiri tepung roti kadaluwarsa, ikan asin kadaluwarsa (busuk/duri ikan sisa warung/tulang sisa), kotoran puyuh/ayam dan kotoran sapi. selain itu ditambahkan minyak ikan yang didapat dari rebusan ikan busuk dan sebagai perekat (matrik) memakai rebusan/lumer dari sampah bulu ayam, dengan perbandingan $1: 1$. Artinya 1 bagian tepung roti kadaluwarsa, 1 bagian lumer ikan asin/ikan busuk, 1 bagian kotoran puyuh/ayam dan kotoran sapi, 1 bagian sampah lumer bulu ayam dan minyak ikan secukupnya. Selanjutnya diaduk manual sampai rata dan adonan siap dicetak dengan memasukkan ke mesin pembuat pelet. Keluarnya pelet yang sudah dicetak, akan jatuh di belt conveyor dan sepanjang pelet tersebut keluar dari mesin maka selalu terkena udara panas dari tungku kompor gas LPG yang udara panasnya disedot menggunakan blower berlawanan arah 
gerakan belt conveyor tersebut, sehingga hasil pelet relatif sudah kering ( \pm kadar air 4\%) atau siap untuk disimpan.

Selanjutnya pelatihan metode pembuatan pakan dan mengatasi masalah produksi. Pelatihan metode pembuatan pakan dan mengatasi masalah produksi dimulai penyiapan materi pelatihan yang didukung contoh bahan pakan, cara mendapatkan, kandungan kepentingan pertumbuhan lele yang ada dibahan pakan, cara mengukur dengan perbandingan dan demo pembuatan atau praktek langsung. Pelatihan akan didukung oleh profesional tentang ternak lele, akademisi dan pemerhati/simpatisan.

\section{PEMBAHASAN}

Hasil rekayasa mesin penghancur, pembuat dan pengering pelet
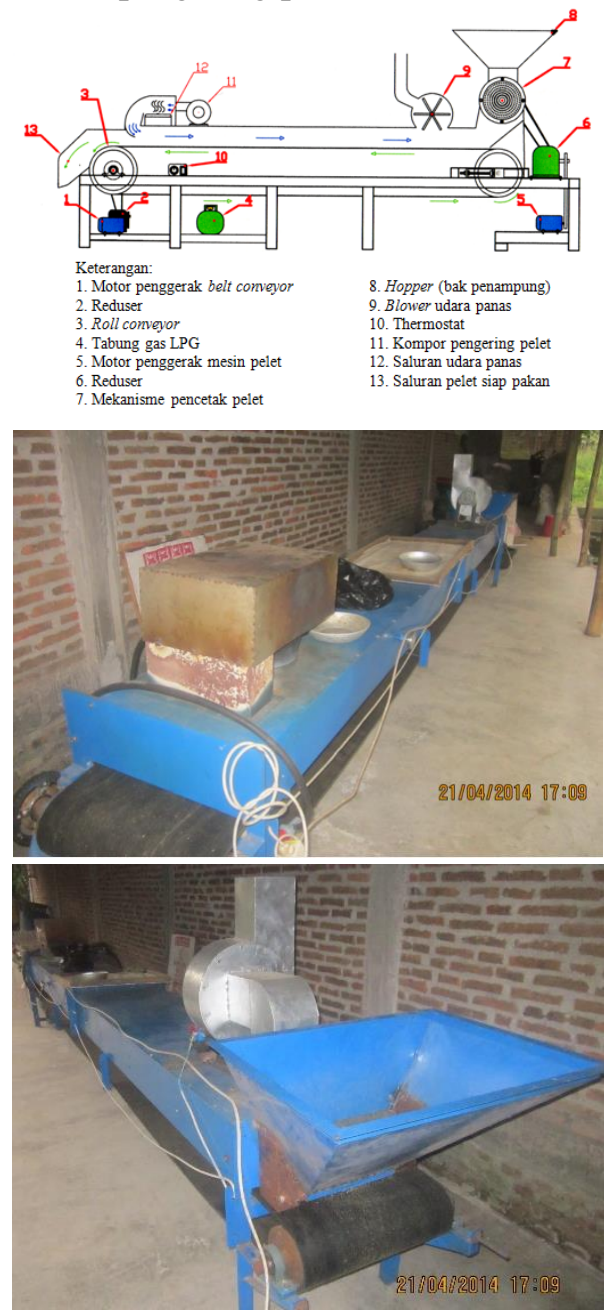

Spesifikasi mesin: (1) Daya listrik yang digunakan 900 watt atau mesin bensin stasioner; (2) Motor listrik $1450 \mathrm{Rpm}$ atau mesin stasiner : $\quad 0,5 \quad-1 \quad \mathrm{Pk}$; (3) Putaran/reduser: $1000-1450 \mathrm{rpm} / 30-40 \mathrm{rpm}$; (4) L: $600 \mathrm{~mm}, \mathrm{t}: 800 \mathrm{~mm}$ dan P: $4000 \mathrm{~mm}$; 95) Panas: $60 \quad{ }^{\circ} \mathrm{C} \quad-80 \quad{ }^{\circ} \mathrm{C}$ optimal; (6) Kapasitas produk: $10-15 \mathrm{~kg} /$ proses atau \pm 200 $\mathrm{kg} / \mathrm{jam}$.

Perbandingan hasil rekayasa mesin/alat, sebelum ada pelaksanaan program pengabdian masyarakat yaitu mitra mengeluarkan untuk pengadaan pakan (pelet) yang dibeli di toko pengecer Saprodi pertanian/perikanan/peternakan yang ada di Kecamatan Jaten dengan harga per sak (30 $\mathrm{kg}$ ) untuk pelet $781-1=\mathrm{Rp} .242 .000,00$ pelet 781-2 = Rp. 237.000,00 dan pelet 781-3 = Rp. 227.000,00 dan harga pakan pelet F999 atau PF $1000($ per/sak $10 \mathrm{~kg})=$ Rp. $10.000,00$ sampai dengan Rp. 12.000,00 per/kg (hargaharga tersebut bersifat fluktuatif atau berkecenderungan meningkat). Asumsi 10000 ekor lele setiap bulannya membutuhkan pakan Rp. 4.500.000,00 hingga Rp. 5.000.000,00. Secara kualitas dan kuantitas mulai penebaran benih sampai panen belum seperti yang diharapkan, hal ini akibat pengaruh negatif faktor luar sehingga pertumbuhannya terhambat. Efeknya perlu memperpanjang umur, menambah biaya pengeluaran pakan dan belum tentu saat penjualan sudah sesuai harga yang diharapkan.

Setelah ada pelaksanaan program pengabdian masyarakat, dengan modal Rp. 2.000.000,00/bulan telah swasembada pakan bahkan beberapa peternak serupa membeli pakan kepada Mitra. Tentunya keuntungan secara ekonomi akan bertambah. Selain itu pengaruh negatif faktor luar dapat diatasi setelah melaksanakan teknik pemberian pakan dengan kualitas pakan (organik), perawatan dengan memperhatikan sirkulasi pengairan diperbaiki.

Keunggulan rekayasa mesin pembuat pakan ikan (pellet) ini sudah dilengkapi 
pengering blower udara panas sehingga jika musim penghujan terjadi kesulitan proses pengeringan atau penjemuran tidak ada masalah lagi. Pelet hasil produksi sudah relatif kering dan beberapa saat (1-2 jam menunggu dingin) dan dapat dilakukan penyimpanan dengan karung pastik

Melalui kegiatan pengabdian masyarakat ini telah diperoleh hasil yaitu Mitra (peternak lele) telah dibekali edukasi teknologi pembuatan pakan lele (pellet) dari macam bahan baku, komposisi, mesin/alat pembuat pellet, proses produksi hingga pengeringan serta penyimpanan, Mitra telah dibekali teknologi pemilihan bibit lele kualitas, pembesaran/ perawatan, kolam ideal, masa panen, strategi penjualan ikan lele secara mandiri ataukelompok, Mitra telah mandiri dan swasembada memproduksi pakan lele (pellet) bahkan sebagian produk dari jumlah hasil produk dibeli oleh ternak lele lain yang membutuhkan.

\section{KESIMPULAN}

Dari hasil rekayasa mesin pembuat pakan ikan lele (pellet) dapat disimpulkan bahwa program pengabdian masyarakat tersebut sangat membantu industri kecil untuk produksi pakan lele secara mandiri dan swasembada.

\section{DAFTAR PUSTAKA}

Anonymous, 2009. Bahan Seminar Penyuluh KP, Dirjen Perikanan Budidaya, Departemen Kelautan dan Perikanan RI.

Anonymos, 2011. Formulasi Pakan Permentasi dan Teknik Pembuatan Pakan Alternatif dengan Bahan Baku Utama Sludge (kotoran sapi), Makalah. Dinas Perikanan dan Kelautan Propinsi Jawa Timur, Unit Pengelola Budidaya Air Tawar Kepanjen-Malang.

Astuti, 1999. Pembuatan Pelet Pakan Ikan dari Limbah Ikan. Jurusan Pendidikan Biologi, FMIPA, UNY Yogyakarta.

Komar Sumantadinata, 1983. Perkembangan Ikan-ikan Peliharaan di Indonesia. PT Sastra Hudaya, Bogor.

Kusmadi, 1994. Pengaruh Substitusi Tepung Cacing Tanah dalam Ransum terhadap Pertambahan Berat dan Panjang lele Dumbo. Jurusan Pendidikan Biologi, FMIPA UNY Yogyakarta.

Masyamsir, 2001. Membuat Pakan Ikan Buatan. Depdiknas, Jakarta.

Prihartono, R. Eko, 2000. Mengatasi Permasalahan Budidaya Lele. Penebar Swadaya, Jakarta (53-69) 